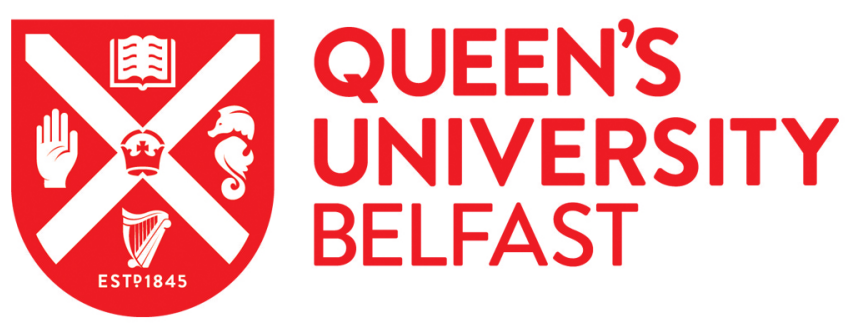

\title{
Attitudes and Knowledge Concerning Corneal Donation in a Population-Based Sample of Urban Chinese Adults
}

Wang, X., Jin, L., Wang, J., Haid Garrett, E., Shuman, J., Yang, K., Schottman, T., Chen, T., Wang, J., Wang, C., \& Congdon, N. (2016). Attitudes and Knowledge Concerning Corneal Donation in a Population-Based Sample of Urban Chinese Adults. Cornea, 35(10), 1362-1367. https://doi.org/10.1097/IC0.0000000000000943

\section{Published in:}

Cornea

\section{Document Version:}

Peer reviewed version

Queen's University Belfast - Research Portal:

Link to publication record in Queen's University Belfast Research Portal

Publisher rights

Copyright $\odot 2016$ Wolters Kluwer Health, Inc. All rights reserved.

\section{General rights}

Copyright for the publications made accessible via the Queen's University Belfast Research Portal is retained by the author(s) and / or other copyright owners and it is a condition of accessing these publications that users recognise and abide by the legal requirements associated with these rights.

Take down policy

The Research Portal is Queen's institutional repository that provides access to Queen's research output. Every effort has been made to ensure that content in the Research Portal does not infringe any person's rights, or applicable UK laws. If you discover content in the Research Portal that you believe breaches copyright or violates any law, please contact openaccess@qub.ac.uk. 
1 Attitudes and Knowledge Concerning Corneal Donation in a Population-Based

2 Sample of Urban Chinese Adults

3

4 Xiuqin Wang, MD, ${ }^{1,2}$ Ling Jin, MS,${ }^{1}$ Jiawei Wang, MPA, ${ }^{1}$ Elizabeth Haid Garrett, ${ }^{3}$

5 Jeremy Shuman, MPH, ${ }^{3}$ Ke Yang, MD, ${ }^{1,6}$ Tim Schottman, ${ }^{3}$ Tingting Chen, MD, ${ }^{1}$ Jun

6 Wang, MD, ${ }^{1}$ Congyao Wang, MD, ${ }^{1}$ and Nathan Congdon, MD, MPH ${ }^{1,4,5}$

1. State Key Laboratory of Ophthalmology and Division of Preventive Ophthalmology,

9 Zhongshan Ophthalmic Center, Sun Yat-sen University, Guangzhou, Guangdong, 10 China.

11 2. Affiliated Hospital of Guangdong Medical College, Zhanjiang, China.

3. SightLife, Seattle, WA, United States.

4. Orbis International, New York, NY, United States.

5. Translational Research for Equitable Eyecare, Center for Public Health, Queen's University Belfast, Belfast N. Ireland

6. Department of Ophthalmology, People's Hospital of Guangxi Zhuang Autonomous Region, Nanning, China

Correspondence: Nathan Congdon, State Key Laboratory of Ophthalmology and Division of Preventive Ophthalmology, Zhongshan Ophthalmic Center, Sun Yat-sen University, Guangzhou, People's Republic of China 510060; and TREE Centre, Centre for Public Health, Queen's University Belfast, 274 Grosvenor Rd, Belfast UK BT12 6BA; ncongdon1@gmail.com.

Commercial Interest: None of the authors has any commercial interest in the devices or techniques discussed in this article.

Funding: Sightlife, Seattle WA; Prof Congdon is supported by the Chinese government's Thousand Man Plan and by the Ulverscroft Foundation

Key Words: Cornea, transplant, donation, knowledge and attitudes, China

MS Length: 2581 words, 5 tables. Abstract: 247 words

Version: 20 May 2016 


\section{Abstract}

Purpose To better understand knowledge and attitudes concerning corneal donation among Chinese adults.

Methods Randomly-selected residents in pre-determined age strata 20-60+ years completed home-based questionnaires in each of 12 randomly-chosen communities in Guangzhou, southern China.

Results Among 1,217 selected persons, 430 (35.3\%) completed questionnaires (mean age 40.4 years, $57.9 \%$ female). Refusers were older (44.8 years, $p<0.001)$, but gender makeup did not differ (52.2\% female, $\mathrm{P}=0.07)$. Among participants, 175 (40.7\%) were willing to donate their corneas (WTD). Differences between WTD and not WTD included: donation knowledge score (range 1-12) (WTD (Standard Deviation, SD) $6.91 \pm 2.21$, not WTD $5.62 \pm 2.43, \mathrm{p}<0.001$ ); having discussed donation (WTD 26.3\%, not WTD 8.63\%, p<0.001); viewing donation as unpopular (WTD 88.0\%, not WTD 96.5\%, p=0.001); and feeling donation "damages the body" (WTD 15.4\%, not WTD 25.7\%, p=0.013). Associated significantly with WTD in multiple regression models were: higher knowledge score $(\mathrm{OR}=1.18,95 \% \mathrm{Cl} 1.04$,

51 1.32, $\mathrm{P}=0.008)$; not feeling donation "damages the body" $(\mathrm{OR}=1.91,95 \% \mathrm{Cl} 1.07$, 3.43, $\mathrm{p}=0.030)$; and willingness to discuss donation $(\mathrm{OR}=10.6,95 \% \mathrm{Cl} 3.35,33.9$, p<0.001). WTD did not differ by age (>60 years: $22 / 51,43.1 \%$; <=60 years: $153 / 379$,

$5440.4 \%, p=0.706)$. Assuming all refusing the survey would not donate, $14.4 \%$ 
55 (175/1217) were WTD for themselves, though only $7.1 \%$ (86/1217) would do so on

56 behalf of a family member if they did not know the deceased's preference.

57 Conclusions Interventions to increase knowledge and promote discussions about

58 donation, as well as policies allowing widespread expression of donation preference,

59 are needed in this setting. 


\section{Introduction}

Corneal opacity is among the world's leading cause of blindness, ranking behind cataract, glaucoma and AMD, but ahead of diabetic retinopathy. ${ }^{1}$ Over 1.5 million persons are blind from corneal opacity, accounting for some $4 \%$ of all global blindness. ${ }^{1}$ In China, the impact of corneal blindness is even greater, accounting for $10-15 \%$ of all blindness and ranking among the top three causes. ${ }^{2,3}$ The overall burden of corneal blindness is further increased when trachoma is included, though non-trachomatous causes are more likely to be treatable. ${ }^{4}$

It has been estimated that $80 \%$ of corneal blindness is preventable. ${ }^{4}$

Nonetheless, transplantation surgery is a highly-effective option for many persons suffering from corneal blindness, with overall long-term success rates as high as 80$90 \% .{ }^{5,6}$ While 50,000 corneal transplantations are performed annually in the United

States, ${ }^{4}$ in China, with its far larger population and higher prevalence of blinding corneal disease, only about 5000 such surgeries are done each year. ${ }^{7,8}$ The principal

74 limitation is a lack of donor tissue, ${ }^{7}$ a requirement for all of the various types of corneal transplant surgery commonly performed today. ${ }^{4}$

Practical barriers to corneal donation have been described as including lower educational and economic levels, older age, lack of knowledge about the process and specific cultural beliefs inconsistent with donation. ${ }^{8-10}$ Previous studies on donation of other tissues besides cornea among persons of Chinese heritage on 
have highlighted important barriers related to specific Chinese cultural beliefs: the

81 body is traditionally thought of as a gift from the parents, which should not be

82 damaged or altered, even after death. ${ }^{11-13}$ Additionally, concerns about mis-use or

83 sale of donated tissue, presumably reflecting a more widespread lack of trust in the

84 medical system, has been identified as a barrier. ${ }^{11,13,14}$ Finally, under Chinese law, ${ }^{15}$

85 next-of-kin must agree to donation of any organ after death, even if the deceased has

86 clearly expressed a wish to donate. ${ }^{16}$ Though the law nominally applies only to organ

87 donation and not tissues such as the cornea, in actual fact, eye banks in China also

88 follow this practice. This de facto veto power on the part of immediate relatives

89 means that their attitudes play a very significant role in donation, and must be

90 understood.

91 Though knowledge and attitudes among ethnically Chinese persons about organ

92 and tissue donation, including corneas, have been studied, 11, 12, 14, 17-21 few

93 investigations ${ }^{11}$ have taken a population approach in order to better understand the

94 situation in the community at large, and none of these population studies have

95 focused on corneal donation. Further, those few studies of corneal donation in China

96 have not generally focused on knowledge and attitudes of potential donors. In the

97 current manuscript, we describe knowledge and attitudes towards corneal donation

98 for oneself and for close relatives in a population-based sample of urban Chinese

99 residents in Guangzhou, southern China, selected to include a pre-determined

100 number of respondents across various age strata. Our hypothesis was that younger 
101 persons would be significantly more receptive to donation for themselves and family 102 members, and less influenced by traditional Chinese cultural attitudes. 


\section{Materials and Methods}

This project was carried out as part of the preparation for SightLife, a US-based non-governmental organization focusing on corneal transplantation, to initiate programs in China. The protocol for this study was approved in full by the Ethics

107 Committee at Zhongshan Ophthalmic Center, Sun Yat-sen University (Guangzhou, China). Written informed consent was given by all participants, and the principals of the Declaration of Helsinki were followed throughout.

\section{Sampling and Enrollment Criteria} Among nine municipal districts (Yuexiu, Liwan, Tianhe, Baiyun, Luogang, Haizhu,

112 Nansha, Panyu and Huangpu) comprising Guangzhou city, southern China, three

113 were selected at random (Liwan, Tianhe and Panyu). Twelve communities were

114 randomly selected from among a total of 484 in the selected three districts. A registry

115 of residencies was obtained from the local government, including approximately

11613,000 households. A household was selected at random as a starting point, and

117 then every tenth household in the community was selected. In each household, one

118 person was selected using a random number table, with enrollment continuing

119 until >= 35 persons had been enrolled in the community, including a minimum of 5

120 persons in each age stratum $20-30,31-40,41-60$ and $>60$ years. The only exclusion

121 criteria were physical or mental conditions precluding completing the questionnaire or 122 giving informed consent. 


\section{Questionnaire}

124 The questionnaire used in the current study was adapted from Lawlor et al, ${ }^{10}$ due

125 to that study's focus on the impact of views on disfigurement and knowledge about

126 the donation process on attitudes towards and acceptance of donation. The

127 questionnaire used in the current study contained 36 items arranged in eight

128 sections: (1) Demographic information, (2) Knowledge and awareness of corneal

129 donation, (3) Social group influences, (4) Perceived benefits of donation, (5) Barriers

130 to donation, (6) Cultural attitudes, (7) Willingness to donate and (8) Motivators toward 131 donation.

The investigators were aware that questions concerning the death of a loved one

133 are highly culturally sensitive in China, and that careful wording of the questionnaire

134 would be needed to avoid very high refusal rates in the setting of a door-to-door

135 survey. Two pilot studies were conducted to test the sensitivity of the questionnaire

136 and adjust wording as needed before the full study began. In each pilot, ten residents

137 of Guangzhou City aged 20 to 60 years were identified in clinics and offices at

138 Zhongshan Ophthalmic Center. In the first, respondents were requested to answer

139 an early draft of the questionnaire, with refusals to answer individual questions being

140 recorded. In the second pilot, respondents were asked to grade the sensitivity of

141 each question on a revised draft using a Likert scale (5 Very uncomfortable to

142 answer to 1 Very comfortable to answer), without actually responding to questions. 
143 On the basis of the two pilots, the most sensitive questions were eliminated

144 altogether, sensitive wording was replaced ("die" with "pass away," "cornea" with

145 "material", etc.) and the order of the questions was rearranged to place the most

146 sensitive questions at the end.

\section{Data collection}

Trained, experienced investigators from a local government-affiliated survey firm

149 made a total of three attempts to contact each household identified as above

150 (Sampling and Enrollment) by knocking on the door. Age and gender were recorded

151 for all persons refusing participation in the survey, and those agreeing to take part

152 were requested to complete the survey on the spot. Respondents answered

153 questions on their own, without discussing the contents with the interviewers, who

154 answered questions as needed.

\section{Statistical Methods}

The total population of Guangzhou City at the end of 2011 (the most recent year

157 available) according to household registers was $8,145,797 .{ }^{22}$ The sample size for the

158 survey was calculated using the formula: $N=\left[\left(2^{*} Z^{\alpha / 2 *} P^{\star}(1-P)\right) /\left(M^{2} E^{2}\right)\right]^{\star}$ Deff, where $\alpha$

159 represented a Type I error of $0.05, \mathrm{P}=0.4$ was the estimated rate of willingness to

160 donate, $\mathrm{MOE}=0.06$ was the margin of error (maximum tolerated error) and Deff $=\mathrm{a}$

161 design effect of 1.5, describing the loss of sampling efficiency due to use of a cluster

162 sampling design. Two publically-available websites ${ }^{23,24}$ were used to carry out the 
163 calculations, and gave identical results: 384 valid respondents were required for the

164 survey according to the above parameters. Adjusting for an expected non-response

165 rate of $65 \%$ based on experience of the firm with similar door-to-door surveys, the

166 expected number of persons needed to be contacted 384/0.35 $=1097$ persons.

167 The main outcome of the study was the willingness of the respondent to donate

168 his/her own cornea. A secondary outcome was willingness to donate on behalf of a

169 relative. Both questions required a definite yes or no answer. Age and sex were

170 compared between those accepting and refusing participation in the survey. Basic

171 demographic characteristics, knowledge and attitudes were compared between those

172 who would and would not donate. Multiple logistic regression models were used to

173 assess the relationship between the main outcome of willingness to donate and

174 potential predictors. The motivators and statements selected by respondents from a

175 prepared list as playing a role in their willingness or unwillingness to donate their own

176 corneas or those of family members were ranked by the proportion of participants

177 selecting them. Analyses were performed using Stata 12.0 (StataCorp, College

178 Station, TX) using the survey features, which account for the effects of cluster

179 sampling. 


\section{Results}

A total of 1217 persons were randomly selected for investigation. Among these, 787 (64.7\%) refused participation, and 430 (35.3\%) accepted. Refusers had a mean age \pm SD of $44.8 \pm 13.8$ years, and 408 (52.2\%) were female, while participants were significantly younger $(40.4 \pm 15.6$ years, $\mathrm{P}<0.001)$ but did not differ significantly by gender makeup. (Table 1) Among participants, 175 (40.7\% of enrollees, $14.4 \%$ of total) indicated they would be willing to donate their own cornea (WTD). Their age, gender, religion, education, income, marriage status and role in parents' medical care did not differ significantly from those $(n=255,59.3 \%)$ who would not donate (Table 2$)$. Table 3 summarizes differences in knowledge and attitude between those who would and would not donate. Significant differences included: donation knowledge score (WTD mean knowledge score \pm SD $6.91 \pm 2.21$ on a scale of $1-12$, not WTD $5.62 \pm 2.43, \mathrm{p}<0.001$ ); having ever discussed donation (WTD 26.3\%, not WTD 8.63\%, p<0.001); viewing donation as "unpopular" in society (WTD 88.0\%, not WTD 96.5\%, $p=0.001)$; feeling donation "damages the body" (WTD 15.4\%, not WTD 25.7\%, p=0.013); being "unlikely" to discuss donation (WTD 67.4\%, not WTD 98.0\%, p<0.001); and "unlikely" to permit donation of a relative's corneas (WTD 60.6\%, not WTD 95.7\%, $p<0.001)$. Those willing and unwilling to donate did not differ in the perception that donated material may be frequently misused in China (WTD 28.0\%, not WTD 33.7\%, $P=0.206)$.

In multiple logistic regression models of potential determinants of WTD (Table 4), 
202 the following remained significant: having higher knowledge score (OR=1.18, 95\%

203 confidence interval $[\mathrm{Cl}], 1.04-1.32, \mathrm{P}=0.008)$, not feeling donation "damages the

204 body" (OR=1.91, 95\% Cl, 1.07-3.43, p=0.030), willingness to discuss donation

$205(\mathrm{OR}=10.6,95 \% \mathrm{Cl}, 3.35-33.9, \mathrm{P}<0.001)$, and being likely to give consent for donation

206 of a family member's corneas (OR=10.3, 95\% Cl, 4.84-21.8; $\mathrm{P}<0.001)$ (Table 4).

207 Respondents were asked about willingness to consent for donation of a loved

208 one's corneas under two different circumstances: 48.4\% (207/428) would consent if

209 they knew that the deceased had wished it, while $20.2 \%(86 / 426)$ would do so if

210 unaware of the wishes of the deceased (answers were not provided by two and four

211 respondents under the first and second scenario respectively). Responses were not

212 associated with the age or gender of the respondent under either scenario, and

213 predictors of a positive response in regression models were similar to those for

214 willingness to donate on one's own behalf (data not shown).

215 The four most important reasons for not being willing to donate one's cornea or

216 consent to donation on behalf of a family member were: "I do not like thinking about

217 death" (49\% self, 33\% relative); "I am concerned the materials might be bought and

218 sold on the black market" (45\% self, 38\% relative); "I would just not feel comfortable

219 about it" (40\% self, 35\% relative); and "I feel the body should be buried whole" (35\%

220 self, 58\% relative). (Table 5) (Data on consent on behalf of a family member are not

221 shown.) The most popular statements identified as playing a role in being willing to

222 donate one's own cornea included "two blind people can see again" (57.1\%), "Allows 
223 something positive to come out of the donor's life" (46.3\%) and "Feel like I am part of 224 solving blindness problems in my community" (41.7\%). The most popular specific 225 motivators for donation of one's own corneas included donor family support groups 226 (32.6\%), thank you letters from recipients (30.9\%) and thank you letters from the eye 227 bank (26.9\%) (Table 5, on line only) 228 


\section{Discussion}

230 While over $40 \%$ of participants in the current study indicated they would be willing

231 to donate their own corneas, this result must be placed in the context of the high

232 refusal rate (nearly two-thirds) among those selected on a population basis.

233 Assuming that all those refusing to take part would also have refused to donate, the

234 proportion willing to donate would still be $14.4 \%(175 / 1217)$. It must also be

235 remembered, however, that under current Chinese law ${ }^{15}$ and eye banking practices,

236 family members have a de facto veto power over donation of a deceased relative's

237 organs and tissues. While respondents were even more willing (48.4\% versus

$23840.7 \%$ ) to authorize donation on behalf of a deceased relative than for themselves

239 when they knew the deceased approved of donation, the proportion was less than

240 half this (20.2\%) when the preference of the deceased was not known. As only

$24116.1 \%$ of all respondents had ever had a conversation about donation, this makes it

242 more likely that the wishes of a deceased potential donor would not be known by

243 family members. Applying the conservative assumption that all refusing participation

244 in this survey would have been unwilling to authorize donation on behalf of a loved

245 one, and that none were certain of the preferences of the deceased, we may

246 estimate that $7.1 \%(86 / 1217)$ of persons in this Chinese urban setting might agree to

247 donation of a deceased relative's corneas.

248 These results have implications for Chinese policy-makers seeking to increase

249 the amount of corneal tissue available for transplant. As outlined above, allowing 
250 persons to make their own choice for donation prior to death could potentially double

251 the rate of positive responses compared to a relative deciding on behalf of a

252 decedent whose wishes s/he did not know. Effective and widespread programs

253 allowing individuals to record their donation wishes, and policies requiring that those

254 wishes be honored when clearly stated, would appear to be effective options to

255 increase donation. In the United States for example, a desire to donate can be

256 expressed at the time of registration for a driver's license in many states, ${ }^{25}$ and

257 similar policies exist in other countries as well, 10,26 though few with cultural beliefs

258 about the sanctity of the body such as exist in China. In the United States; ${ }^{25,}{ }^{27}$ and

259 in many European countries, ${ }^{28}$ organ donation can be authorized with the

260 individual's own consent, without requiring that the family agree. Various countries in

261 the European Union, Wales being the earliest, ${ }^{28}$ have some form of presumed

262 consent, also referred to as an "opt-out system," which has led in settings such as

263 Spain to rates of cadaveric organ donation (33.6 per million inhabitants), and kidney

264 and liver transplantation (50.6 and 24.2 per million respectively), which are among

265 the highest in the world. ${ }^{29,} 30$

266 Regarding other predictors of willingness to donate and their implications for

267 program design, our hypothesis that younger respondents would be more willing to

268 donate proved to be untrue for either self-donation or authorization on behalf of a

269 relative. The association between donation and both greater knowledge about, and a

270 willingness to discuss, the process suggests that interventions to increase donation 
271 might focus on education and promoting family discussions. Results from the Barriers

272 and Motivators sections of the study can also inform future programs: concern over

273 misuse of tissue is a top-ranking concern with regard to both self-donation and that

274 on behalf of relatives. Efforts to make the donation process highly transparent and

275 eye banks fully accountable are needed, together with public education aimed at

276 promoting these ideas. Motivators ranked highly by respondents, such as donor

277 family support groups and thank you letters, may also be useful to increase donation.

278 In accord with other studies, ${ }^{11}$ the current report underscores the fact that

279 donation is a very sensitive topic in China. High proportions of respondents find

280 thoughts or discussions about death and donation uncomfortable and unwelcome,

281 while still subscribing to the idea that the body should remain intact in death.

282 Nonetheless, if our calculations above are correct that one in fourteen persons in this

283 setting might authorize donation on behalf of a relative, then programs which actively

284 contact bereaved families to seek consent may be practical at sufficiently large

285 hospitals. While such programs are common in the United States and Europe,

286 donation in China generally depends on relatives to take the initiative. We have

287 begun a pilot program to train donation coordinators at two hospitals in Guangdong

288 Province for family outreach, and plan to test interventions based on findings of the

289 current study using a randomized controlled design in these pilot projects.

290 The main strength of the current study is its population design involving

291 community-residing persons over a wide age range, together with the relatively 
292 detailed questionnaire. A principal weakness is the high refusal rate, despite

293 considerable effort to frame the questionnaire in an inoffensive way. While home

294 surveys may be prone to yield such high refusal rates, it has been suggested that the

295 impact on representativeness of the sample may not be large. ${ }^{31}$ Additional

296 weaknesses include the fact that participants were speculating about their response

297 in the event of the death of a loved one, rather than being interviewed after an actual

298 such occurrence. We hope to address this shortcoming in future work.

299 Despite these limitations, this is first population-based study of attitudes towards

300 corneal donation in China, and it provides useful information for project planners

301 seeking to start programs in that challenging setting. 


\section{Acknowledgements}

303 Funding Financial Supported by SightLife (Seattle, WA), Prof Congdon is supported 304 by the Chinese government Thousand Man Plan and by the Ulverscroft Foundation. 


\section{References}

307 1. Pascolini D, Mariotti SP. Global estimates of visual impairment: $2010 . \mathrm{Br} \mathrm{J}$ 308 Ophthalmol 2012;96:614-618.

309 2. Liang Y, Friedman DS, Wong T, et al. Prevalence and causes of low vision and 310 blindness in a rural chinese adult population: the Handan Eye Study. Ophthalmology $311 \quad 2008 ; 115: 1965-1972$.

312 3. Xu L, Wang Y, Li Y, et al. Causes of blindness and visual impairment in urban and 313 rural areas in Beijing: the Beijing Eye Study. Ophthalmology 2006;113:1134-1141.

314 4. Lamm V, Hara H, Mammen A, et al. Corneal blindness and xenotransplantation. 315 Xenotransplantation 2014;21:99-114.

316 5. Thompson RW Jr, Price MO, Bowers PJ, et al. Long-term graft survival after 317 penetrating keratoplasty. Ophthalmology 2003;110:1396-1402.

318 6. Borderie VM, Boelle PY, Touzeau O, et al. Predicted long-term outcome of corneal 319 transplantation. Ophthalmology 2009;116:2354-2360.

320 7. Zhang M. Strategies to resolve the problem of lack of keratoplasty materials in

321 China. Chin J Ophthalmol 2007;43:289-292. (Chinese)

322 8. Afshar R, Sanavi S, Rajabi M. Attitude and willingness of high school students 323 toward organ donation. Saudi J Kidney Dis Transpl 2012;23:929-933.

324 9. McGlade D, McClenahan C, Pierscionek B. Attitudes underlying corneal donation 325 in a group of trainee allied health professionals. PloS One 2012;7:e53538.

326 10. Lawlor M, Kerridge I, Ankeny R, et al. Specific unwillingness to donate eyes: the 
327 impact of disfigurement, knowledge and procurement on corneal donation. Am J 328 Transplant 2010;10:657-663.

329 11. Yeung I, Kong SH, Lee J. Attitudes towards organ donation in Hong Kong. Soc 330 Sci Med. 2000;50:1643-1654.

331 12. Chu T, Wang L, Yu H, et al. Awareness of cornea donation of registered tissue 332 donors in Nanjing. Chin Med Sci J 2013;28:20-27.

333 13. Xie S, Woo SM, Zhang L. Strategies for changing negative public attitudes toward 334 organ donation in the People's Republic of China. Patient Prefer Adherence 2014;8:2533530.

336 14. Chen J, Zhang T, Lim F, et al. Current knowledge and attitudes about organ 337 donation and transplantation among Chinese university students. Transplant Proc $338 \quad 2006 ; 38: 2761-2765$.

339 15. Decree of the State Council of the people's Republic of China (No. 491st) -

340 human organ transplantation Ordinance. Available at:

341 http://www.moh.gov.cn/mohzcfgs/pfg/200804/29213.shtml. Accessed September 24, 3422015 (Website in Chinese.)

343 16. China human organ donation registration process. Available at:

344 http://www.rcsccod.org.cn/articleDetailView.shtml?articleld=ff808081453f2d1301453f

345 3408d70008\&moduleld=2c90a85f4110a883014110af55500003\&moduleType=2\&sitel $346 \mathrm{~d}=f f 808181126$ bebda01126bec4dd00001. Accessed October 4, 2015 (Website in 347 Chinese.) 
348 17. Wu AMS, Tang CS. The negative impact of death anxiety on self-efficacy and

349 willingness to donate organs among Chinese adults. Death Stud 2009;33:51-72.

350 18. Liu Y, Lei H, Qui F. Investigation of attitudes towards organ transplantation in young 351 people in China. Chin Med J (Engl) 1997;110:210-215.

352 19. Tam WW, Suen LK, Chan HY. Knowledge, attitudes and commitment toward organ

353 donation among nursing students in Hong Kong. Transplant Proc 2012;44:1196-1200.

354 20. Hu D, Huang H. Knowledge, Attitudes, and Willingness Toward Organ Donation 355 Among Health Professionals in China. Transplantation 2015;99:1379-1385.

356 21. Zhang L, Li Y, Zhou J, et al. Knowledge and willingness toward living organ 357 donation: a survey of three universities in Changsha, Hunan Province, China. 358 Transplant Proc 2007;39:1303-1309.

359 22. Registered Households and Population at Year-end by District and County-level 360 City (2011). Available at: http://data.gzstats.gov.cn/gzStat1/chaxun/njsj.jsp. Accessed 361 September 24, 2015 (Website in Chinese.)

362 23. WHO | STEPS Sample Size Calculator and Sampling Spreadsheet. Available 363 at: http://www.who.int/chp/steps/resources/sampling/en/. Accessed September 24, 3642015.

365 24. Sample size calculator. Available at: http://www.raosoft.com/samplesize.html. 366 Accessed September 24, 2015.

367 25. Nathan HM, Conrad SL, Held PJ, et al. Organ donation in the United States. Am 368 J Transplant 2003;3:29-40. 
369 26. Wellesley H. A nudge in the right direction for organ donation--but is it enough?.

370 BMJ 2011:343:d5726

371 27. Orentlicher D. Presumed consent to organ donation: its rise and fall in the United

372 States. Rutgers Law Review 2009;61:295-331.

373 28. UK Transplant Laws. Available at: http://www.organdonationscotland.org/uk-

374 transplant-laws. Accessed November 2, 2015.

375 29. Matesanz R. A decade of continuous improvement in cadaveric organ donation:

376 the Spanish model. Nefrologia 2001;21:59-67.

377 30. Abadie A, Gay S. The impact of presumed consent legislation on cadaveric organ

378 donation: a cross country study J Health Econ 2006;25:599-620.

379 31. Holbrook AL, Krosnick JA, Pfent A. The Causes and Consequences

380 of Response Rates in Surveys by the News Media and Government Contractor Survey

381 Research Firms. Advances in Telephone Survey Methodology. New York: John Wiley

382 \& Sons, Inc. 2008:499-678. 
Table 1: Basic demographic information for those accepting and refusing participation in the survey

\begin{tabular}{|c|c|c|c|c|}
\hline Characteristics & $\begin{array}{c}\text { All } \\
(\mathrm{N}=1217)\end{array}$ & $\begin{array}{c}\text { Refuse } \\
\text { participation } \\
(\mathrm{N}=787 \\
64.7 \%)\end{array}$ & $\begin{array}{c}\text { Accept } \\
\text { participation } \\
(\mathrm{N}=430 \\
35.3 \%)\end{array}$ & $\begin{array}{c}\text { P-value } \\
\text { comparing } \\
\text { refusing vs. } \\
\text { accepting } \\
\text { participation* }\end{array}$ \\
\hline Age, y, n (\%)† & & & & $<0.001$ \\
\hline $20-30$ & $352(29.0)$ & $200(25.6)$ & $152(35.4)$ & \\
\hline $31-40$ & $258(21.3)$ & 169 (21.6) & $89(20.7)$ & \\
\hline $41-50$ & $274(22.6)$ & $196(25.1)$ & 78 (18.1) & \\
\hline $51-60$ & $200(16.5)$ & 140 (17.9) & $60(14.0)$ & \\
\hline$>60$ & $128(10.6)$ & 77 (9.85) & $51(11.9)$ & \\
\hline Mean (SD) & $43.2(14.6)$ & $44.8(13.8)$ & $40.4(15.6)$ & \\
\hline \multicolumn{5}{|l|}{ Sex, n (\%)‡ } \\
\hline Female & $657(54.2)$ & $408(52.2)$ & 249 (57.9) & 0.070 \\
\hline Male & $554(45.8)$ & $373(47.8)$ & 181 (42.1) & \\
\hline
\end{tabular}

* Taking the effects of cluster sampling into account, simple linear regression was used for age and logistic regression was used for sex to compare the difference between groups.

†: $5(0.41 \%)$ persons who refused participation had missing data for age.

‡: $6(0.49 \%)$ persons who refused participation had missing data for sex. 
Table 2: Demographic information by willingness to donate

\begin{tabular}{|c|c|c|c|c|}
\hline Characteristics & $\begin{array}{c}\text { All } \\
(\mathrm{N}=430)\end{array}$ & $\begin{array}{l}\text { Would } \\
\text { donate } \\
(n=175)\end{array}$ & $\begin{array}{l}\text { Would not } \\
\text { donate } \\
(\mathrm{n}=255)\end{array}$ & P-value $\ddagger$ \\
\hline Age, y, n (\%) & & & & 0.699 \\
\hline 20-30 & $152(35.3)$ & 58 (33.1) & $94(36.9)$ & \\
\hline $31-40$ & $89(20.7)$ & $41(23.4)$ & $48(18.8)$ & \\
\hline $41-50$ & 78 (18.1) & $29(16.6)$ & $49(19.2)$ & \\
\hline $51-60$ & $60(14.0)$ & $25(14.3)$ & 35 (13.7) & \\
\hline$>60$ & $51(11.9)$ & $22(12.6)$ & $29(11.4)$ & \\
\hline Mean (SD) & $40.4(15.6)$ & $40.7(15.4)$ & $40.1(15.7)$ & \\
\hline Sex, n (\%) & & & & 0.597 \\
\hline Female & 249 (57.9) & $104(59.4)$ & 145 (56.9) & \\
\hline Male & 181 (42.1) & $71(40.6)$ & $110(43.1)$ & \\
\hline Religion, n (\%) & & & & 0.741 \\
\hline None & $369(85.8)$ & 149 (85.1) & $220(86.3)$ & \\
\hline Buddhist/Christian/Other & $61(14.2)$ & $26(14.9)$ & $35(13.7)$ & \\
\hline Education, n (\%)* & & & & 0.246 \\
\hline None/Elementary school & $52(12.1)$ & $16(9.14)$ & $36(14.2)$ & \\
\hline Junior school & $168(39.2)$ & $66(37.7)$ & $102(40.2)$ & \\
\hline High school & $112(26.1)$ & $47(26.9)$ & $65(25.6)$ & \\
\hline College or above & $97(22.6)$ & $46(26.3)$ & $51(20.1)$ & \\
\hline $\begin{array}{l}\text { Income, RMB per month, } \mathbf{n} \\
(\%) \dagger\end{array}$ & & & & 0.149 \\
\hline$<2000$ & $104(24.5)$ & $38(21.8)$ & $66(26.4)$ & \\
\hline $2000-4000$ & $197(46.5)$ & 75 (43.1) & $122(48.8)$ & \\
\hline $4001-6000$ & $86(20.3)$ & $43(24.7)$ & $43(17.2)$ & \\
\hline$>6000$ & 37 (8.73) & $18(10.3)$ & $19(7.60)$ & \\
\hline Marriage status, n (\%) & & & & 0.482 \\
\hline $\begin{array}{l}\text { Married and living with } \\
\text { spouse }\end{array}$ & $309(71.9)$ & $129(73.7)$ & $180(70.6)$ & \\
\hline Single & $121(28.1)$ & $46(26.3)$ & $75(29.4)$ & \\
\hline \multicolumn{5}{|l|}{$\begin{array}{l}\text { Role in parents' medical } \\
\text { care, } n(\%) \S\end{array}$} \\
\hline No living parents & $73(17.0)$ & 34 (19.4) & 39 (15.3) & 0.262 \\
\hline $\begin{array}{l}\text { Have living parents, takes } \\
\text { an active role }\end{array}$ & $122(28.4)$ & $45(25.7)$ & 77 (30.2) & 0.311 \\
\hline $\begin{array}{l}\text { Have living parents, but } \\
\text { takes no role }\end{array}$ & $212(49.3)$ & 86 (49.1) & $126(49.4)$ & 0.956 \\
\hline $\begin{array}{l}\text { Spouses' parents living, } \\
\text { takes an active role }\end{array}$ & $70(16.3)$ & $26(14.9)$ & $44(17.3)$ & 0.508 \\
\hline $\begin{array}{l}\text { Spouses' parents living, } \\
\text { takes no role }\end{array}$ & $174(40.5)$ & $72(41.1)$ & $102(40.0)$ & 0.812 \\
\hline
\end{tabular}

*: $1(0.23 \%)$ person unwilling to donate group had missing education data.

†: $6(1.40 \%)$ persons ( 1 willing and 5 unwilling to donate) had missing income data.

$\ddagger$ : Taking the effects of cluster sampling into account, simple linear regression was used for age, ordinal logistic regression was used for education and income, and logistic regression was used for all other variables in comparing the difference between groups. 
§: Participants could select more than one choice, so the total numbers exceeded 430. 
Table 3: Knowledge and attitudes among those who would and would not donate

\begin{tabular}{|c|c|c|c|}
\hline Item & $\begin{array}{l}\text { Would } \\
\text { Donate } \\
(n=175)\end{array}$ & $\begin{array}{l}\text { Would not } \\
\text { Donate } \\
(n=255)\end{array}$ & $\begin{array}{c}\text { P-value comparing } \\
\text { would vs. would } \\
\text { not donate* }\end{array}$ \\
\hline $\begin{array}{l}\text { Knowledge summary score, Mean } \\
\text { (SD) } \dagger\end{array}$ & $6.91(2.21)$ & $5.62(2.43)$ & $<0.001$ \\
\hline $\begin{array}{l}\text { Ever had conversation about } \\
\text { donation, } \mathbf{n}(\%)\end{array}$ & & & $<0.001$ \\
\hline Yes & $46(26.3)$ & $22(8.63)$ & \\
\hline No & $129(73.7)$ & $233(91.4)$ & \\
\hline \multicolumn{4}{|l|}{ Social and cultural attitudes, n (\%) } \\
\hline $\begin{array}{l}\text { Corneal donation is generally } \\
\text { popular in society }\end{array}$ & & & 0.001 \\
\hline $\begin{array}{l}\text { Not sure/disagree/strongly } \\
\text { disagree }\end{array}$ & $154(88.0)$ & $246(96.5)$ & \\
\hline Agree/strongly agree & $21(12.0)$ & $9(3.53)$ & \\
\hline $\begin{array}{l}\text { The body is a gift from the } \\
\text { parents } \ddagger\end{array}$ & & & 0.476 \\
\hline $\begin{array}{l}\text { Not sure/disagree/strongly } \\
\text { disagree }\end{array}$ & $15(8.57)$ & $27(10.7)$ & \\
\hline Agree/strongly agree & $160(91.4)$ & $226(89.3)$ & \\
\hline Donation damages the body $\ddagger$ & & & 0.013 \\
\hline $\begin{array}{l}\text { Not sure/disagree/strongly } \\
\text { disagree }\end{array}$ & $148(84.6)$ & $188(74.3)$ & \\
\hline Agree/strongly agree & $27(15.4)$ & $65(25.7)$ & \\
\hline $\begin{array}{l}\text { Donated material may be } \\
\text { frequently misused in China } \S\end{array}$ & & & 0.206 \\
\hline $\begin{array}{l}\text { Not sure/disagree/strongly } \\
\text { disagree }\end{array}$ & $126(72.0)$ & $167(66.3)$ & \\
\hline Agree/strongly agree & $49(28.0)$ & $85(33.7)$ & \\
\hline \multicolumn{4}{|l|}{$\begin{array}{l}\text { Attitudes towards discussion and } \\
\text { proxy consent, } \mathbf{n}(\%)\end{array}$} \\
\hline Willing to discuss donation & & & $<0.001$ \\
\hline $\begin{array}{l}\text { Not sure/disagree/strongly } \\
\text { disagree }\end{array}$ & $118(67.4)$ & $247(98.0)$ & \\
\hline Agree/strongly agree & $57(32.6)$ & $5(1.98)$ & \\
\hline $\begin{array}{l}\text { Likely to give consent to } \\
\text { donate a loved one's cornea } \ddagger\end{array}$ & & & $<0.001$ \\
\hline $\begin{array}{l}\text { Not sure/disagree/strongly } \\
\text { disagree }\end{array}$ & $106(60.6)$ & $242(95.7)$ & \\
\hline Agree/strongly agree & $69(39.4)$ & $11(4.35)$ & \\
\hline
\end{tabular}

* Taking the effects of cluster sampling into account, simple linear regression was used for knowledge score and logistic regression was used for all other variables in comparing the difference between groups.

†: 8 (1.86\%) persons had missing data. 
‡: $2(0.46 \%)$ persons had missing data.

$\S$ : $3(0.70 \%)$ persons had missing data. 
Table 4: Multiple logistic regression model of potential determinants of willingness to donate one's own cornea, adjusting for effects of cluster sampling (Items significant at the $\mathrm{P}<0.05$ level are highlighted in bold) $(\mathrm{N}=419)^{*}$

\begin{tabular}{lcc}
\hline Variable & OR (95\% Cl) & P-value \\
\hline Age, per year & $0.99(0.98,1.01)$ & 0.487 \\
$\begin{array}{l}\text { Female sex } \\
\text { Knowledge score, (range: } \mathbf{0 - 1 2})\end{array}$ & $1.35(0.84,2.17)$ & 0.217 \\
$\begin{array}{l}\text { Ever had conversation about } \\
\text { donation }\end{array}$ & $1.18(\mathbf{1 . 0 4 , 1 . 3 2 )}$ & $\mathbf{0 . 0 0 8}$ \\
$\begin{array}{l}\text { Considers corneal donation } \\
\text { popular in society }\end{array}$ & $1.57(0.51,2.63)$ & 0.725 \\
$\begin{array}{l}\text { Not feeling donation "damages } \\
\text { the body" }\end{array}$ & $\mathbf{1 . 9 1 ( 1 . 0 7 , 3 . 4 3 )}$ & 0.543 \\
$\begin{array}{l}\text { Willing to discuss donation } \\
\begin{array}{l}\text { Likelihood of giving consent to } \\
\text { donate a loved one's cornea }\end{array}\end{array}$ & $\mathbf{1 0 . 6 ( 3 . 3 5 , 3 3 . 9 )}$ & $\mathbf{0 . 0 3 0}$ \\
\hline OR: & $\mathbf{1 0 . 3 ( 4 . 8 4 , ~ 2 1 . 8 )}$ & $<0.001$ \\
\hline
\end{tabular}

OR: odds ratio $\mathrm{Cl}$ : confidence interval

* Age, sex and variables with $\mathrm{P}<=0.2$ in table 2 were included in the multiple regression model. 
Table 5. Statements that play a role in not being willing to donate (Asked only of 255 persons not willing to donate their own corneas), and Statements and motivators that play a role in willingness to donate corneas (Asked only of 175 persons willing to donate their own corneas)

Statements that would play a role in your decision to not pledge to donate your corneas

I do not like thinking about death

I am concerned (corneal) materials are being bought and sold on the black

market

I am not sure of the reasons, I would just not feel comfortable about it

The body should be buried whole

My vision is not good enough to donate

I don't feel I have enough information to agree to donation

I don't want to give up such an important part of my physical appearance

Eyes are needed in the afterlife

Other reasons

It is against my religious beliefs

\section{Statements that play a role in willingness to donate corneas}

Two blind people will be able to see again/be cured

Corneal donation allows something positive to come out of the

donor's life

I feel like I am part of solving public health/ blindness problems in

my community

I would gain merit that might affect my position in the next life

I would feel good about myself because of having made this

\section{decision.}

Because helping others is an important part of being a good person

It is important that material are made available for research into

causes of blindness

I would feel good about making the decision to donate on behalf of a loved one

It helps families of the deceased grieve

Other reasons

\section{Motivators that play a role in willingness to donate corneas}

Donor family support group

Thank you letter from the recipient

Thank you letter from the eye bank

Donor family ceremony/ celebration 
